\title{
Assessment of Women's Dietary Diversity in Southern Senegal
}

\author{
Jean Augustin Diégane Tine, Khadim Niang, Adama Faye, Anta Tal Dia \\ Department of Preventive Medicine and Public Health of the Cheikh Anta Diop University of Dakar (UCAD), \\ Institut de Sante et Developpement (ISED), UCAD, Dakar, Senegal \\ Email: leki105@ya hoo.fr, jeanaugustin.tine@ucad.edu.sn
}

How to cite this paper: Tine, J.A.D., Niang, K., Faye, A. and Dia, A.T. (2018) Assessment of Women's Dietary Diversity in Southern Senegal. Food and Nutrition Sciences, 9, 1192-1205. https://doi.org/10.4236/fns.2018.910086

Received: September 11, 2018

Accepted: October 16, 2018

Published: October 20, 2018

Copyright ( 92018 by authors and Scientific Research Publishing Inc. This work is licensed under the Creative Commons Attribution International License (CC BY 4.0).

http://creativecommons.org/licenses/by/4.0/

(c) (i) Open Access

\begin{abstract}
Introduction: Lack of dietary diversity is a nutritional problem among poor people in developing countries whose daily diet is usually based on a starch source with one or two additional components. Senegal has food insecure regions such as Kolda and Kedougou despite improved agricultural production. This study aims to investigate the determinants of dietary diversity in the Kolda and Kedougou regions. Methodology: It was a cross-sectional, descriptive and analytic household-level study in two southern regions of Senegal (Kolda and Kedougou) between October and December 2015. This was a three-stage random sample survey. Dietary diversity in women of reproductive age was measured using the Women's Dietary Diversity Score (WDDS) recommended by Food and Agriculture Organization of the United Nations (FAO). The WDDS is a global qualitative indicator of nutrition, which counts the number of food groups consumed by a person in the 24 hours preceding the survey. The data was collected during an individual interview. Linear regression was used to identify the associated factors of dietary diversity. The free and informed consent of the individuals surveyed and the protection of anonymity were respected. Results: A total of 1926 women were surveyed. The mean of WDDS was 2.9 with a standard deviation of 1.4. The Kedougou department has a better WDDS with $3.3( \pm 1.2)$ followed by the Kolda department with a score of $3.2( \pm 1.3)$. The higher the household's welfare score, the better the WDDS with a $\beta$ coefficient of 0.11 [0.09 - 0.13]. Households that are in urban areas have a better score than households in rural areas $(0.27$ [0.13 - 0.41]). The improvement of knowledge in food diversification, in good culinary practice improves the dietary diversity score in women. Conclusion: The WDDS is low in the southern regions of Senegal. To improve dietary diversification in this area, the practice of good cooking practices, the accessibility of micronutrient-rich foods, and the decision-making power of women in the household should be promoted.
\end{abstract}




\section{Keywords}

Dietary Diversity, Women, Kolda, Kedougou, Senegal

\section{Introduction}

Dietary diversity is an important concept in the fight against malnutrition, whether by excess or by default in all age groups, especially in developing countries. It is the secret of a healthy and balanced diet for women. Dietary diversity determines the number of different food groups consumed by an individual or household over a given period of time. At the international level, dietary guidelines recommend the consumption of a sufficient variety of foods, which is supposed to ensure adequate intakes of nutrients essential for good health [1] [2]. In the 1950s these recommendations were based on high protein diets, then high energy diets, and more recently, efforts have been made to eliminate micronutrient deficiencies through supplementation and fortification of foods [3]. Although agricultural production is sufficient for all of humanity, 840 million people do not have enough food in the world [4]. In developing countries, the precarious living conditions of households have a negative impact on the nutritional status of women and children. Experiments measuring dietary diversity in Africa are rare and are more common in young children [5] [6].

Having noted the consequences of unbalanced diets in women and children, the Food and Agriculture Organization of the United Nations (FAO) has enacted the measure of dietary diversity score was considered a good tool to help measure the overall quality of diets, both in industrialized countries and developing countries [7] [8] [9].

The nutritional status of women as they become pregnant and during pregnancy can have a significant influence on the health of the fetus, infant and mother [10]. Common maternal malnutrition results in insufficient fetal development and increased risk of pregnancy complications. Undernutrition in both mother and child is responsible for more than $10 \%$ of the global burden of disease [11].

In 2012, Senegal experienced a food crisis characterized by a significant decline in agricultural production of all cultivated species. Between 2013 and 2014, the number of people affected by severe food insecurity increased from 675,000 to about 927,500 , and the number of people living under stress from 1.9 million to 2.86 million [12]. The number of people requiring humanitarian assistance has increased from 9\% to 31\% between 2013 and 2015 [13]. This decline has created a difficult food situation in Kolda and Kedougou that has affected household eating habits and altered nutritional quality [14].

In Senegal, according to the Demographic and Health Survey with Multiple Indicators (EDS MICS-2015), stunting in children was evaluated in 2015 at 
$20.5 \%$. The proportion of children suffering from wasting was $7.8 \%$ and underweight was $15.5 \%$. The proportion of overweight children was $0.3 \%$ [15]. The non-dietary diversification in pregnant women impacts the survival and health of the child, which becomes a breeding ground for the occurrence of chronic malnutrition and is characterized by stunting, morbidity, risk of death, disorders of cognitive and motor development, low physical and intellectual performance [10].

The Rural Food Security and Nutrition Survey (ERASAN-2014) in Senegal showed that $43.2 \%$ of households had a low dietary diversity score and $46.4 \%$ an average score. In the southern departments of Senegal such as Saraya and Medina Yoro Foulah, more than $60 \%$ of households consume fewer than three food groups per week [14].

With all these observations, it is opportune to understand dietary diversification through this study which has the general objective of studying the factors associated with dietary diversity among women of reproductive age in the Kolda and Kedougou regions of Senegal.

\section{Framework of the Study}

This study was conducted in southern Senegal in the Kolda and Kedougou regions (as shown in Figure 1). These two regions are among the most disadvantaged regions of Senegal. The Kolda region is made up of three departments: Kolda, Vélingara and Médina Yoro Foulah (MYF). The region of Kédougou is also composed of three departments: Kédougou, Saraya and Salémata. According to the results by region of EDS-MICS 2010-2011 indicators of maternal and child health are worrying and all the determinants of maternal mortality are more accentuated, mortality of children under 5 years (per thousand): Kolda (154), Kedougou (145) and Senegal (72); prevalence of chronic malnutrition: Kolda (24\%), Kedougou (28.35\%) and Senegal (16.5\%). Difficult access to health and social services (only $36.6 \%$ of the population in Kolda and $30.1 \%$ in Kedougou) and the lack of resources available to support the most vulnerable groups, especially women, are factors that contribute to this situation and the deterioration of the living conditions of the poorest [16].

\section{Methodology}

This is a quantitative, cross-sectional, descriptive and analytical study that was conducted in the last quarter of 2015.

The study concerned households in the six departments of southern Senegal where women of reproductive age (aged 15 to 45 ) freely agreed to participate in the study and were present on the day of collection.

The sample size was calculated from the Hsieh formula. It was appreciated with a risk of $5 \%$ and a power of $90 \%$. The correlation coefficient (r) is estimated between the dietary diversity score and the household welfare index [17] [18]. 


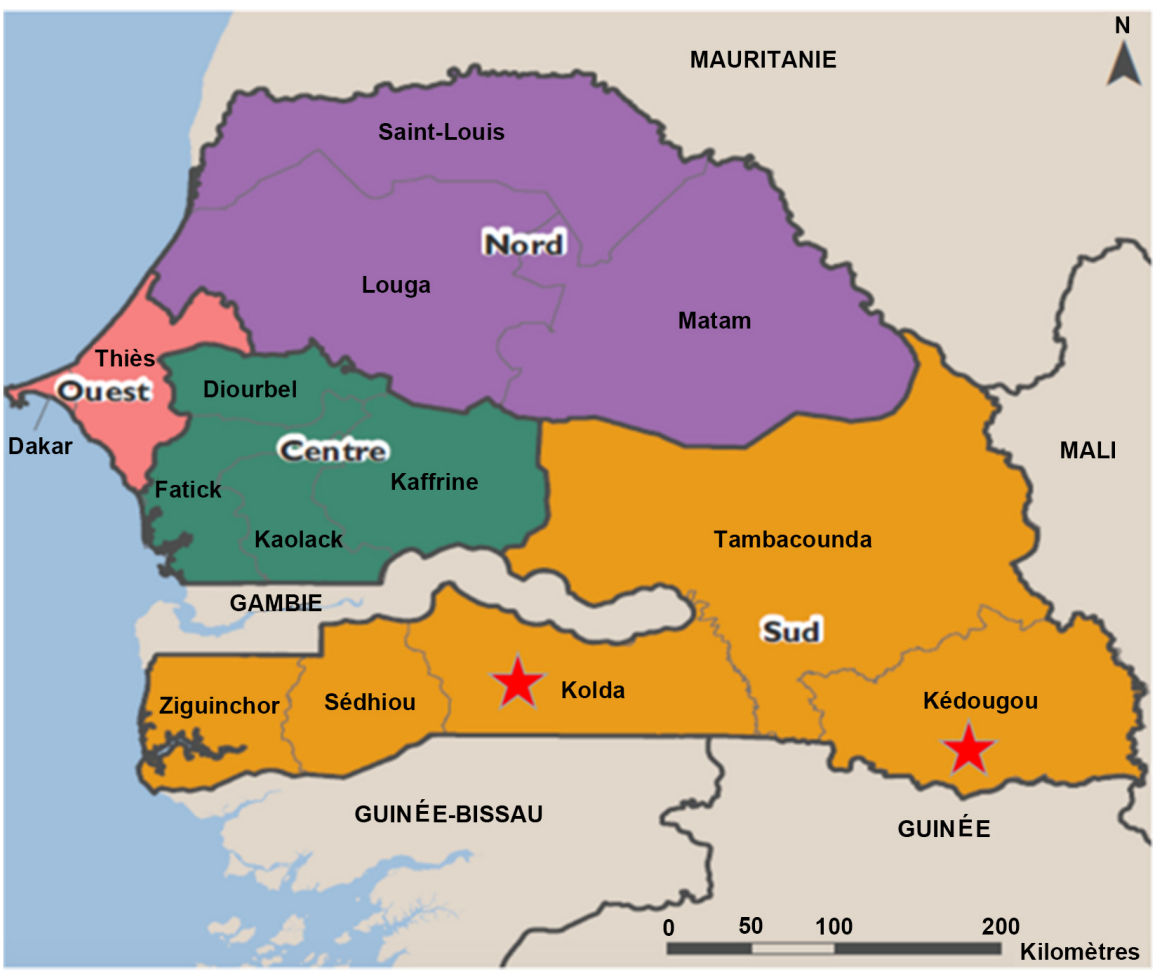

Figure 1. Map of Senegal (ANSD, 2014).

$$
\begin{gathered}
N=\left(Z_{1-\alpha / 2}-Z_{1-\beta}\right)^{2} / C(r)^{2}+3 \\
C(r)=1 / 2 \log ((1+r) /(1+r))
\end{gathered}
$$

$$
\begin{aligned}
& r=0.25 \\
& Z_{1-\alpha / 2}=1.96 \\
& Z_{1-\beta}=1.29
\end{aligned}
$$

Design effect $=2$

The sample size calculated taking into account the plan effect is 1724 households. With a non-respondent rate estimated at $10 \%$, the final size is 1900 households. In each household a woman of reproductive age will be selected.

A three-stage random survey was conducted. The first stage consisted of drawing the census districts (CDs) represented by the villages or neighborhoods, the second degree by the households, and the third degree by the drawing of the woman of reproductive age to be surveyed. In total, the study was conducted at 16 census districts by department. In each census district, 20 households were selected. At the DR level, the first grant was drawn, and the others are chosen consecutively. A systematic draw was made according to the number of households. In each household, a random draw of a woman was made on the census list of women of reproductive age in the household.

Data collection was based on electronic questionnaires (by CSpro Software). The investigators were responsible for collecting the data directly on the tablets. They were organized in 18 teams each of which was guided by a team leader. In each department, there was a supervisor. After four days of training, the investi- 
gators conducted a pilot survey to test the questionnaires before starting the data collection.

Dietary diversity was appreciated through the number of food groups that women consumed in the 24 hours prior to the survey. In line with the recommendations of the World Food Program (WFP) for measuring the WDDS, nine food groups were searched. The nine food groups are: 1) Cereals, roots and tubers 2) Legumes 3) Nuts and seeds 4) Dairy products 5) Meat products 6) Giblets 7) Eggs 8) Dark green leafy vegetables 9) Fruits and vegetables rich in vita$\min \mathrm{A}$.

The woman said she ate and drank at breakfast, at lunch, at dinner including snacks inside or outside the household the night before the survey. The dietary diversity score was used to classify women according to the diet [19].

The household well-being index (WBI) was measured by the Unified Questionnaire Indicators of Well-being Base (QUIBB) Version 2011 [20].

Data were analyzed with the R-Studio 3.4.4 software. The description of the variables is made with absolute and relative frequencies and the quantitative variables by the mean and standard deviation. Multivariate analysis was performed with a multiple linear regression for determining the factors related to food diversity, with adjustment independent variables ensuring the applicability conditions with a significance level set at $5 \%$. The variables with $\mathrm{p}$ was less than 0.25 in bivariate analysis were selected for modeling. ANOVA and AIC allowed the choice of the last with the method of stepping down [21]. Finally, the R squared (coefficient of determination) was used to test the quality of the final linear regression model. The associations were measured by regression coefficients $\beta$ with their confidence intervals [22] [23].

The approval of the National Ethics Committee for Health Research (CNERS) of Senegal has been obtained before the start of field activities. Participation in the study was free. A free and informed consent was obtained from women. A fact sheet was administered to each individual before signing the consent form. This study did not provide any remuneration or compensation for those surveyed. The data collected remained confidential. The identity of the individuals who agreed to participate was not mentioned on collection tools. In all uses of the results, anonymity was respected.

\section{Results}

\subsection{Characteristics of Women of Reproductive Age}

The average age of women surveyed was 27.2 years with a standard deviation of 7.6 years. The median age was 26 years. Married women were the majority. Polygamous households were $40.8 \%$. The proportion of women who had a good knowledge about good nutrition practices was $11.6 \%$. Those who had a high level of knowledge of good food hygiene practices were $12.3 \%$. A small proportion (3.2\%) knew the good nutritional practices taking into account the micronutrients. (As shown in Table 1). 
Table 1. Characteristics of women of reproductive age $(\mathrm{N}=1926)$.

\begin{tabular}{|c|c|c|}
\hline CHARACTERISTICS OF WOMEN & $\begin{array}{c}\text { absolute } \\
\text { frequencies } \\
\text { (n) }\end{array}$ & $\begin{array}{c}\text { relative } \\
\text { frequencies } \\
(\%)\end{array}$ \\
\hline \multicolumn{3}{|l|}{ Marital status } \\
\hline monogamous married & 1090 & 56.6 \\
\hline Polygamous married & 785 & 40.8 \\
\hline Widower & 23 & 1.2 \\
\hline Single & 18 & 0.9 \\
\hline Divorced & 10 & 0.5 \\
\hline \multicolumn{3}{|l|}{ Level of women education } \\
\hline No & 1349 & 70.0 \\
\hline Primary & 392 & 20.4 \\
\hline Secondary & 176 & 9.1 \\
\hline Superior & 9 & 0.5 \\
\hline \multicolumn{3}{|l|}{ Level of knowledge of women about good nutrition practices } \\
\hline Low & 867 & 45.0 \\
\hline Moderate & 835 & 43.4 \\
\hline High & 224 & 11.6 \\
\hline \multicolumn{3}{|l|}{ Women's level of knowledge about good food hygiene practices } \\
\hline Low & 831 & 43.1 \\
\hline Moderate & 859 & 44.6 \\
\hline High & 236 & 12.3 \\
\hline \multicolumn{3}{|l|}{$\begin{array}{l}\text { Level of knowledge of women of good cooking practices that preserve } \\
\text { micronutrients }\end{array}$} \\
\hline Low & 1315 & 68.3 \\
\hline moderate & 549 & 28.5 \\
\hline high & 62 & 3.2 \\
\hline$\%$ Of women with income generating activity & 513 & 26.6 \\
\hline$\%$ Of women experiencing diversification of food consumed & 343 & 17.8 \\
\hline$\%$ Of women experiencing micronutrient-rich foods marketed in the area & 1314 & 68.2 \\
\hline$\%$ Of women who consume nutritious food in sufficient quantity & 751 & 39.0 \\
\hline$\%$ Of women experiencing exclusive breastfeeding from birth to 6 months & 878 & 45.6 \\
\hline$\%$ Women who meet food hygiene requirements & 941 & 48.9 \\
\hline$\%$ Women who meet adequate food preservation & 390 & 20.2 \\
\hline$\%$ Women who respect good cooking practices & 396 & 20.6 \\
\hline$\%$ Women who practice balanced diet & 267 & 13.9 \\
\hline$\%$ Women who practice child complementary feeding at six months from & 1096 & 56.9 \\
\hline
\end{tabular}




\section{Continued}

\begin{tabular}{|c|c|c|}
\hline$\%$ Women who practice hand washing before handling and eating food & 1311 & 68.1 \\
\hline $\begin{array}{l}\text { \% Women who respect the cleanliness of the cooking area and food } \\
\text { preservation }\end{array}$ & 774 & 40.2 \\
\hline$\%$ Women who respect the cleanliness of food consumption areas & 846 & 43.9 \\
\hline$\%$ Women who practice the washing of utensils before use & 1122 & 58.3 \\
\hline$\%$ Women who practice cooking at the right temperature & 359 & 18.6 \\
\hline$\%$ Women who practice proper food preservation & 275 & 14.3 \\
\hline$\%$ Of women who use a good drainage system of household waste & 170 & 8.8 \\
\hline$\%$ Of women who use the well-preserved water & 393 & 20.4 \\
\hline
\end{tabular}

\subsection{Households Characteristics}

The average household well-being index (WBI) was 5.8 with a standard deviation of 3.1. The median well-being index was 5 . The correlation coefficient between the WDDS and the WBI obtained during the analysis was 0.32 with a confidence interval of [0.22-0.36].

The majority of the households surveyed lived in rural areas (76.2\%). Most households had between seven and twelve people (39.9\%). Poor households accounted for $34 \%$. For $83.6 \%$ of households, women controlled less than $50 \%$ of household expenses. There were $62.8 \%$ of households with fruit trees and $55.7 \%$ of households that had livestock. (As shown in Table 2).

\subsection{Women's Dietary Diversity Score (WDDS)}

The mean of WDDS was 2.9 with a standard deviation of 1.4. The WDDS was weak overall in the six departments. The Saraya Department has the lowest WDDS with an average score of 2.4 with a standard deviation of 1.3 , as shown in Table 3.

Boxplots of Figure 2 shows the distribution of food diversity scores per department. The median of the distribution of the WDDS is lower at Salemata and Saraya.

\subsection{Factors Associated with Women's Dietary Diversity Score}

Multiple linear regression showed that increasing of WBI increases the WDDS. More monthly household income, the greater the WDDS increases (0.24 [0.13 to $0.36])$. Households in urban areas have better WDDS the rural households $(0.27$ [0.13 to 0.41$])$. The availability of land under irrigation, the practice of the inland fishing, processing of local products, the preparation of micronutrient-rich foods are factors that increase the WDDS. The R squared of the linear regression model was 0.23 . Table 4 shows the factors associated with WDDS.

\section{Discussion}

This study made it possible to understand the factors associated with dietary diversification among women in Senegal in predominantly rural areas where food 
Table 2. Characteristics of households $(\mathrm{N}=1926)$.

\begin{tabular}{|c|c|c|}
\hline HOUSEHOLD CHARACTERISTICS & $\begin{array}{l}\text { absolute } \\
\text { frequencies } \\
\text { (n) }\end{array}$ & $\begin{array}{c}\text { relative } \\
\text { frequencies } \\
(\%)\end{array}$ \\
\hline \multicolumn{3}{|c|}{ GEOGRAPHICAL FEATURES } \\
\hline \multicolumn{3}{|l|}{ Department } \\
\hline Kedougou & 320 & 16.6 \\
\hline Kolda & 321 & 16.7 \\
\hline Medina Yoro Foulah (MYF) & 328 & 17.0 \\
\hline Salemata & 320 & 16.6 \\
\hline Saraya & 318 & 16.5 \\
\hline Velingara & 319 & 16.6 \\
\hline \multicolumn{3}{|l|}{ Geographical area } \\
\hline rural & 1467 & 76.2 \\
\hline urban & 459 & 23.8 \\
\hline \multicolumn{3}{|l|}{ Household size } \\
\hline$[0-6]$ & 442 & 22.9 \\
\hline$[7-12]$ & 769 & 39.9 \\
\hline [13 or more] & 715 & 37.2 \\
\hline \multicolumn{3}{|l|}{ ECONOMIC FEATURES } \\
\hline \multicolumn{3}{|l|}{ Poverty quintile } \\
\hline Very rich & 41 & 2.0 \\
\hline Rich & 157 & 8.2 \\
\hline Way & 550 & 28.6 \\
\hline Poor & 655 & 34.0 \\
\hline Very poor & 523 & 27.2 \\
\hline \multicolumn{3}{|l|}{ Economic Household } \\
\hline Less than the minimum wage & 580 & 30.1 \\
\hline Minimum wage and more & 1346 & 69.9 \\
\hline \multicolumn{3}{|l|}{ Share of expenditures female-controlled } \\
\hline Less than $50 \%$ & 1611 & 83.6 \\
\hline $50 \%$ or more & 315 & 16.4 \\
\hline \multicolumn{3}{|c|}{ AVAILABILITY IN AGRICULTURAL RESOURCES } \\
\hline$\%$ Of households with fruit trees & 1206 & 62.6 \\
\hline$\%$ Of households with land under irrigation & 343 & 17.8 \\
\hline$\%$ Of household who practice gardening & 489 & 25.4 \\
\hline $\begin{array}{l}\% \text { Of household living in a village with a community granary } \\
\text { for children }\end{array}$ & 92 & 4.8 \\
\hline
\end{tabular}




\section{Continued}

\begin{tabular}{|c|c|c|}
\hline \multicolumn{3}{|c|}{ PRACTICAL NUTRITION HOUSEHOLD } \\
\hline$\%$ Of households engaged in fishing & 81 & 4.2 \\
\hline$\%$ Of households who practice fish farming & 11 & 0.6 \\
\hline$\%$ Of households that keep livestock & 1072 & 55.7 \\
\hline$\%$ Households who practice the culture of bio-fortified seeds & 283 & 14.7 \\
\hline$\%$ Households who practice the processing of local products & 194 & 10.1 \\
\hline $\begin{array}{l}\% \text { Households who practice the marketing of processed local } \\
\text { products fortified with micronutrients }\end{array}$ & 130 & 6.7 \\
\hline $\begin{array}{l}\% \text { Households who practice the preparation of meals rich in } \\
\text { micronutrients }\end{array}$ & 228 & 11.8 \\
\hline
\end{tabular}

Table 3. Breakdown of dietary diversity score of women according to departments.

\begin{tabular}{ccccc}
\hline \multirow{2}{*}{ departments } & \multicolumn{4}{c}{ Woman's Dietary Diversity Score } \\
\cline { 2 - 5 } & Mean & SD & Median & Effective \\
\hline Kedougou & 3.3 & 1.2 & 3 & 320 \\
Kolda & 3.2 & 1.3 & 3 & 321 \\
Medina Yoro Foulah & 3.0 & 1.4 & 3 & 328 \\
Salemata & 2.6 & 1.2 & 2 & 320 \\
Saraya & 2.4 & 1.3 & 2 & 318 \\
Velingara & 2.8 & 1.6 & 3 & 319 \\
Total & 2.9 & 1.4 & 3 & 1926 \\
\hline
\end{tabular}

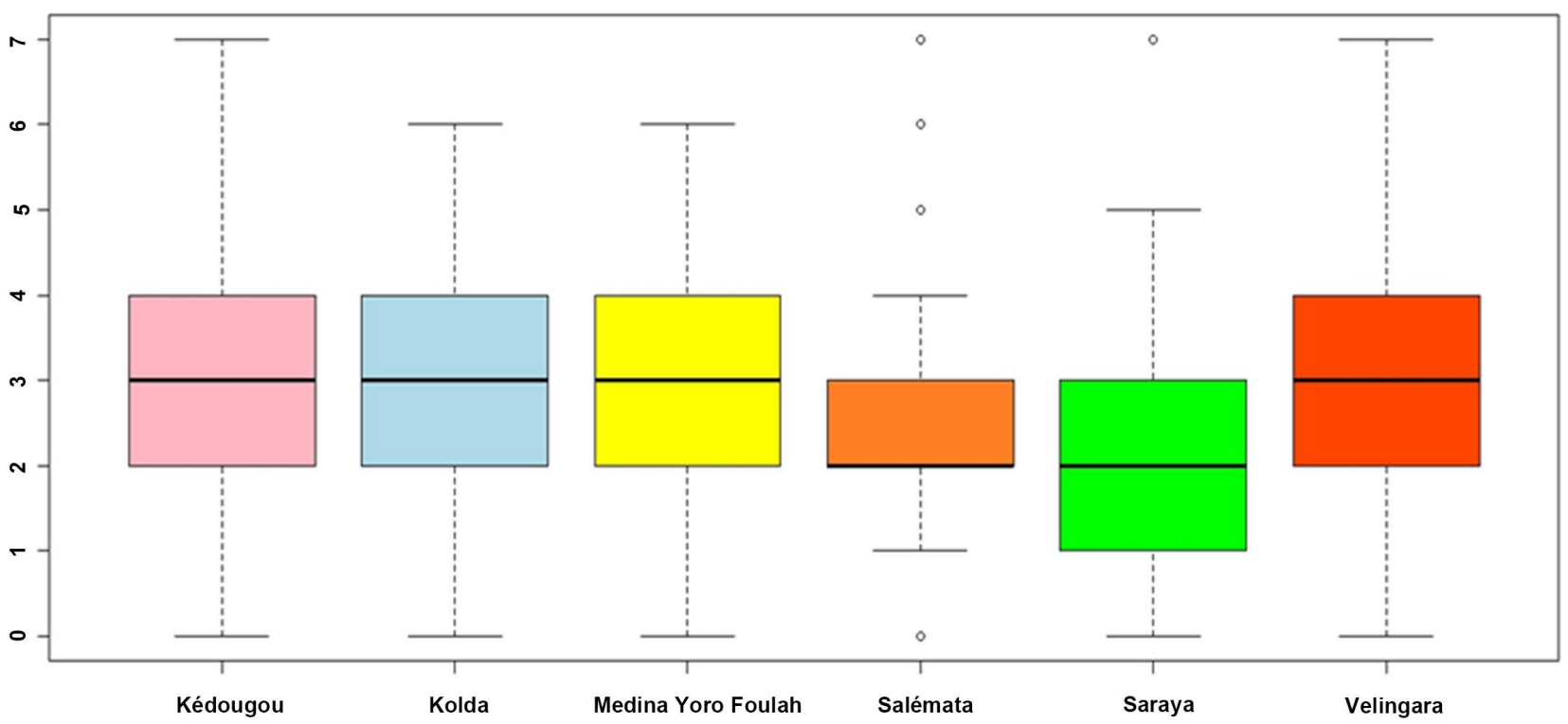

Figure 2. Boxplot WDDS comparison between departments.

insecurity is important. The limit of this research is the lack of quantification of consumption. The seven-day diversification assessment was not used because of the memory bias. 
Table 4. Factors associated with WDDS (multiple linear regression modeling).

\begin{tabular}{|c|c|c|c|c|}
\hline \multicolumn{2}{|l|}{ Factors } & $\begin{array}{c}\text { coefficient } \\
\beta\end{array}$ & $\begin{array}{c}\text { confidence } \\
\text { interval } 95 \%\end{array}$ & pvalue \\
\hline \multicolumn{2}{|c|}{ household Well-Being Index } & 0.11 & {$[0.09 ; 0.13]$} & $<0.001$ \\
\hline \multirow{6}{*}{ Departments } & Kedougou & ref & & \\
\hline & Kolda & -0.23 & {$[-0.43 ;-0.04]$} & 0.020 \\
\hline & $\begin{array}{l}\text { Medina Yoro } \\
\text { Foulah }\end{array}$ & -0.61 & {$[-0.81 ;-0.41]$} & $<0.001$ \\
\hline & Salemata & -0.57 & {$[-0.78 ;-0.37]$} & $<0.001$ \\
\hline & Saraya & -0.61 & {$[-0.82 ;-0.41]$} & $<0.001$ \\
\hline & Velingara & -0.31 & {$[-0.51 ;-0.11]$} & 0.002 \\
\hline \multirow{4}{*}{ Monthly household income } & Rural & ref & & \\
\hline & Urban & 0.27 & {$[0.13 ; 0.41]$} & $<0.001$ \\
\hline & $\begin{array}{l}\text { less than } \\
\text { minimum wage }\end{array}$ & ref & & \\
\hline & $\begin{array}{l}\text { Minimum wage } \\
\text { and More }\end{array}$ & 0.24 & {$[0.13 ; 0.36]$} & $<0.001$ \\
\hline \multirow{2}{*}{$\begin{array}{l}\text { Households with plots } \\
\text { under irrigation }\end{array}$} & No & ref & & \\
\hline & Yes & 0.22 & {$[0.07 ; 0.37]$} & 0.005 \\
\hline $\begin{array}{l}\text { Households who practice } \\
\text { marketing of processed local }\end{array}$ & No & ref & & \\
\hline $\begin{array}{l}\text { products fortified with } \\
\text { micronutrients }\end{array}$ & Yes & 0.34 & {$[0.20 ; 0.47]$} & 0.000 \\
\hline \multirow{2}{*}{ Households who fish } & No & ref & & \\
\hline & Yes & 0.28 & {$[0.001 ; 0.55]$} & 0.046 \\
\hline \multirow{2}{*}{$\begin{array}{l}\text { Households who practice } \\
\text { the transformation of local } \\
\text { products }\end{array}$} & No & ref & & \\
\hline & Yes & 0.19 & {$[-0.02 ; 0.40]$} & 0.072 \\
\hline $\begin{array}{l}\text { Households who practice } \\
\text { the preparation of meals }\end{array}$ & No & ref & & \\
\hline rich in micronutrients & Yes & 0.48 & {$[0.23 ; 0.73]$} & $<0.001$ \\
\hline \multirow{2}{*}{$\begin{array}{c}\text { Share of spending controlled } \\
\text { by the woman in the } \\
\text { household }\end{array}$} & Less than $50 \%$ & ref & & \\
\hline & $50 \%$ or more & 0.25 & {$[0.09 ; 0.40]$} & 0.001 \\
\hline \multirow{2}{*}{$\begin{array}{l}\text { Knowledge of diversification } \\
\text { of food consumed }\end{array}$} & No & ref & & \\
\hline & Yes & 0.22 & {$[0.07 ; 0.37]$} & 0.005 \\
\hline \multirow{2}{*}{$\begin{array}{l}\text { Knowledge of } \\
\text { micronutrient-rich foods } \\
\text { marketed in the area }\end{array}$} & No & ref & & \\
\hline & Yes & 0.35 & {$[0.22 ; 0.47]$} & $<0.001$ \\
\hline \multirow{3}{*}{$\begin{array}{l}\text { Level of knowledge of } \\
\text { women of good cooking } \\
\text { practices that preserve } \\
\text { micronutrients }\end{array}$} & High & ref & & \\
\hline & Way & -0.19 & {$[-0.53 ; 0.14]$} & 0.256 \\
\hline & Low & -0.30 & {$[-0.63 ; 0.04]$} & 0.082 \\
\hline
\end{tabular}

The dietary diversity score (DDS) is the main measure of dietary diversity, it can be measured at the household and individual level mainly in pregnant and lactating women or in children. DDS is a determinant of nutrient consumption. The number of food groups consumed has an impact on nutrient adequacy [24] 
[25]. WDDS is used as a proxy measure of the nutritional quality of the diet in women of childbearing, pregnant and lactating age. The dietary diversity score at the individual level is an approximate measure of diet adequacy in macronutrients and/or micronutrients in women [19] [26]. This study found an average WDDS of $2.9( \pm 1.4)$ in the Kolda and Kédougou regions. The study was done before harvesting winter crops. The Saraya Department has a lower food diversity score $(2.4 \pm 1.3)$ despite the existence of gold mining plants in the area. The main economic activity of Saraya is gold panning at the expense of agriculture, fishing and livestock. This behavioral change had an impact on the food security and nutrition of Saraya populations. In Burkina, Savy found a WDDS of $5.1 \pm$ 2.0 among women mothers of children [27].

The study showed that the practice of processing local food products, the practice of fishing, the development of parcels under irrigation by households for agriculture were in favor of a better dietary diversification of women. The development of agriculture in rural areas is an important determinant of household food security [28].

Women's dietary diversification is related to the level of women's involvement in household expenditures. Women who controlled more than $50 \%$ of household expenditures had better dietary diversification (0.25 [0.09-0.40]). The more the woman has better decision-making power in household expenditures, the better the food diversification [27] [28].

The departments of Kédougou and Kolda are the most urbanized in the area and recorded better dietary diversity scores. The analysis showed that the more households living in an urbanized area have a better WDDS than those living in rural areas (0.27 [0.13-0.41]). Women living in urban areas have better access to information and health services than women in the villages. The good knowledge of dietary diversification by women is a factor that improves the score of dietary diversification (0.22 [0.07-0.37]). Women who are familiar with foods rich in micronutrients marketed in the zone's markets have a better dietary diversity (0.35 [0.22-0.47]) [29].

Dietary diversification in pregnant women is of paramount importance, it is essential because it is in different foods that it draws the necessary nutrients for a good development of the child, its survival and its good health [30] [31].

\section{Conclusion}

The WDDS reports on the probability of micronutrient adequacy of women's diets. According to the World Food Program, women who consume less than 4 food groups have a weakly diversified diet, those with 4 to 5 food groups have a moderately diversified diet, and those with more than 5 food groups have a very diverse diet. Our study showed that, on average, women in the Kolda and Kedougou regions have a weakly diversified diet. To combat this low level of dietary diversity, the practice of producing micronutrient-rich animal and plant foods should be promoted, women's knowledge of good nutritional and culinary practices increased, and the decision-making power of women in the household im- 
proved. The poorer the household, the lower the WDDS.

\section{Acknowledgements}

Centre d'Excellence Africain pour la Santé de la mère et de l'enfant (CEASAMEF/UCAD).

The Micronutrient Initiative.

All women who agreed to participate in this survey.

\section{Conflicts of Interest}

The authors declare no conflicts of interest regarding the publication of this paper.

\section{References}

[1] Bronner, F. (1995) Nutrition and Health Topics and Controversies. CRC Press, 272 p.

[2] FAO, Déclaration de Rome sur la Sécurité Alimentaire Mondiale et Plan d'Action du Sommet Mondial de l'Alimentation, Rome, 13-17 Novembre 1996; 48 p.

[3] Thompson, F.E. and Byers, T. (1994) Dietary Assessment Resource Manual. The Journal of Nutrition, 124, 2245S-2317S.

[4] Freudenheim, J.L. (1993) A Review of Study Designs and Methods of Dietary Assessment in Nutritional Epidemiology of Chronic Disease. The Journal of Nutrition, 123, 401-405. https://doi.org/10.1093/jn/123.suppl_2.401

[5] Tarini, A., Bakari, S. and Delisle, H. (1999) The Overall Nutritional Quality of the Diet Is Reflected in the Growth of Nigerian Children. Health Montrouge France, 9 , 23-31.

[6] Leroy, J.L., Habicht, J.P., Ruel, M.T., Simlers, K.R. and Dittoh, S. (2012) Household Dietary Diversity Is Associated with Child Nutritional Status and Dietary Diversity.

[7] FAO (2004) Workshop on Dietary Diversity and Dietary Quality. WHO, IFPRI, 11-13.

[8] Swindale, A. and Bilinsky, P. (2005) Household Dietary Diversity Score (HDDS) for Measurement of Household Food Access: Indicator Guide. Food and Nutrition Technical Assistance Project, Academy for Educational Development, Washington DC.

[9] Rush, D. (2000) Nutrition and Maternal Mortality in the Developing World. The American Journal of Clinical Nutrition, 72, 212s-240s. https://doi.org/10.1093/ajen/72.1.212S

[10] Bhutta, Z.A., Das, J.K., Rizvi, A., Gaffey, M.F., Walker, N., Horton, S., et al. (2013) Evidence-Based Interventions for Improvement of Maternal and Child Nutrition: What Can Be Done and at What Cost? The Lancet, 382, 452-77. https://doi.org/10.1016/S0140-6736(13)60996-4

[11] WHO. Nutrition Challenges. Geneva, 2017 http://www.who.int/nutrition/challenges/fr/

[12] SECNSA, SAP. National Survey on Food Security and Nutrition (ESAN). WFP. Senegal, June 2013.

https://www.humanitarianresponse.info/sites/www.humanitarianresponse.info/files /documents/files/ENSAN-NOTE\%20SYNTHETIQUE\%20SECNSA\%20version-Fin al\%20-8-10\%20-13.pdf 
[13] OCHA. Strategic Response Plan Senegal. HNO December 2014. https://www.unocha.org/sites/dms/ROWCA/Coordination/SRP/2015/Senegal_SRP 2015.pdf

[14] SECNSA, DAPSA, ANACIM. Rural Survey of Food Security and Nutrition (ERASAN). WFP. Senegal, in December 2014.

https://www.secnsa.sn/publications/0824068001486128511ERASAN-rapport-dy-fin itif.pdf

[15] ANSD. Demographic and Health Survey Continues in Senegal (DHS-Continue) 2015. The DHS Program, Dakar, in March 2016.

http://www.ansd.sn/ressources/rapports/EDS\%20CONTINUE\%202015\%20RAPPO RT\%20PRELIMINAIRE-1.pdf

[16] ANSD (2012) Demographic and Health Indicators FINAL Multi-2010-2011-Report. Senegal. https://dhsprogram.com/pubs/pdf/FR258/FR258.pdf

[17] Sokal, R.R. and Rohlf, F.J. (1995) Biometry. WH Freeman and Company, New York, 578.

[18] Hsieh, F.Y., Bloch, D.A. and Larsen, M.D. (1998) A Simpler Method of Sample Size Calculation for Linear and Logistic Regression. Statistics in Medicine, 17, 1623-1634.

[19] Kennedy, G., Ballard, T. and Dop, M.D. (2013) Guide to Measure Dietary Diversity at the Household and Individual. FAO, Rome. http://www.fao.org/3/a-i1983f.pdf

[20] World Bank (2011) Unified Questionnaire Indicators of Well-Being Base (QUIBB). USA.

[21] Venables, W.N. and Ripley, B.D. (2002) Modern Applied Statistics Statistics with S. 4th Edition, Springer, Berlin. https://doi.org/10.1007/978-0-387-21706-2

[22] Brent, P.R. (1973) Algorithms for Minimization without Derivatives, Chapter 4. Prentice-Hall, Englewood Cliffs, NJ.

[23] Burnham, K.P. and Anderson, D.R. (2002) Model Selection and Inference Multimodel: A Practical-Theoretic Approach. 2nd Edition, Springer-Verlag, Berlin.

[24] Hatloy, A., Torheim, L. and Oshaug, A. (1998) Food Variety-A Good Indicator of Nutritional Adequacy of the Diet? A Case Study from an Urban Area in Mali, West Africa. European Journal of Clinical Nutrition, 52, 891-898. https://www.ncbi.nlm.nih.gov/pubmed/9881884

[25] Swindale, A. and Ohri-Vachaspati, P. (2005) Measuring Household Food Consumption: A Technical Guide. FANTA, Washington DC. https://www.k4health.org/sites/default/files/Measuring\%20Household\%20Food.pdf

[26] Martin-Prevel, Y. (2004) Relationship between Food Variety/Diversity Scores and Nutritional Status of Adults and Teenagers in Rural Burkina Faso (Invited Lecture). Joint FAO-WHO-IFPRI Workshop "Dietary diversity and dietary quality”, Rome.

[27] Savy, M., Sawadogo, P., Kamély, Y. and Martin-Prevel, Y. (2004) Measures of Diet Quality with Variety of Scores/Diversity Relationship with the Nutritional Status of Mothers in Rural Burkina Faso. Nutrition Food Companies, 303-308.

[28] Hoddinott, J. and Yohannes, Y. (2002) Dietary Diversity as a Food Security Indicator. FANTA, Washington DC.

[29] Hatloy, A., Hallund, J., Diarra, M.M. and Oshaug, A. (2000) Food Variety, Socioeconomic Status and Nutritional Status in Urban and Rural Areas in Koutiala (Mali). Public Health Nutrition, 3, 57-65. https://doi.org/10.1017/S1368980000000628

[30] Black, R.E., Victora, C.G., Walker, S.P., Bhutta, Z.A., Christian, P., De Onis, M., et al. (2013) Maternal and Child Undernutrition and Overweight in Low-Income and 
Middle-Income Countries. The Lancet, 382, 427-451.

https://doi.org/10.1016/S0140-6736(13)60937-X

[31] Kennedy, G., Pedro, R., Seghieri, C., Nantel, G. and Brouwer, I. (2007) Dietary Diversity Score Is a Useful Indicator of Micronutrient Intake in Non-Breast-Feeding Filipino Children. Journal of Nutrition, 137, 1-6.

https://doi.org/10.1093/jn/137.2.472 